Meta

Journal des traducteurs

Translators' Journal

\title{
Ideology and Translation Studies in Present-Day China
}

\section{Jun Tang}

Volume 50, numéro 4, décembre 2005

Pour une traductologie proactive - Actes

For a Proactive Translatology — Proceedings

Por una traductología proactiva - Actas

URI : https://id.erudit.org/iderudit/019856ar

DOI : https://doi.org/10.7202/019856ar

Aller au sommaire du numéro

Éditeur(s)

Les Presses de l'Université de Montréal

ISSN

0026-0452 (imprimé)

1492-1421 (numérique)

Découvrir la revue

Citer cet article

Tang, J. (2005). Ideology and Translation Studies in Present-Day China. Meta, 50(4). https://doi.org/10.7202/019856ar

\section{Résumé de l'article}

Ce texte a pour but de rechercher la dimension idéologique dans les études de traduction en Chine d'aujourd'hui, perçues comme un indicateur de changement des fluctuations idéologiques de la traduction. En s'appuyant sur le panorama des études de traduction en Chine d'aujourd'hui, l'article montre que le problème concerne les circonstances intérieures, à la fois la société, la culture, la politique et le système de la société chinoise. L'héritage de la culture traditionnelle ou l'influence occidentale ne peuvent servir d'excuse ou de panacée. Le savoir local se trivialise s'il est coupé du contexte global du monde, qui à son tour perd son sens si le savoir local est négligé.
Ce document est protégé par la loi sur le droit d'auteur. L'utilisation des services d'Érudit (y compris la reproduction) est assujettie à sa politique d'utilisation que vous pouvez consulter en ligne.

https://apropos.erudit.org/fr/usagers/politique-dutilisation/ 


\title{
Ideology and Translation Studies in Present-Day China
}

\author{
JUN TANG \\ South China University of Technology, Guangzhou, China \\ j_tangshh@hotmail.com
}

\section{RÉSUMÉ}

Ce texte a pour but de rechercher la dimension idéologique dans les études de traduction en Chine d'aujourd'hui, perçues comme un indicateur de changement des fluctuations idéologiques de la traduction. En s'appuyant sur le panorama des études de traduction en Chine d'aujourd'hui, l'article montre que le problème concerne les circonstances intérieures, à la fois la société, la culture, la politique et le système de la société chinoise. L'héritage de la culture traditionnelle ou l'influence occidentale ne peuvent servir d'excuse ou de panacée. Le savoir local se trivialise s'il est coupé du contexte global du monde, qui à son tour perd son sens si le savoir local est négligé.

\begin{abstract}
This essay examines the ideological dimension of translation studies in present-day China, which can be viewed as an indicator of any discernible change in ideological fluctuations of translation. Based on an overview of translation studies in present-day China, this essay argues that the most urgent problem is the domestic climate for the social, cultural, political, and institutional sub-systems of Chinese society. It is inadvisable to take the traditional cultural heritage or Western influences as the excuse or panacea for current problems in China. Local knowledge can be trivialized if cut off from the global setting, and the global setting becomes meaningless if local knowledge is ignored.
\end{abstract}

\section{MOTS-CLÉS/KEYWORDS}

ideology, translation studies, China, cultural identity, critical and theoretical translation studies

The dynamics of ideology in Chinese translation studies has not obtained due share of academic attention as the aftereffect of the political trauma of the so-called Cultural Revolution (1966-1976). During those ten years of turmoil, intellectual dissenters had been forced to keep silence. Even after the Chinese government had headed for less control and more freedom in 1993 when market economy had been legitimized, a considerable number of Chinese scholars tend to avoid "dangerous" notions such as ideology, criticism (literary, social and academic) and politics. It is especially so for those scholars who had unpleasant experiences in the Cultural Revolution. They try to ignore the existence of politics in the hope that the academic field should be kept "clean" as an uncontaminated area that has nothing to do with the social or political environment. This tendency of de-contextualization, severing texts from their social contexts, had become the 
mainstream in Chinese linguistic and translation studies during the 1980s. The 1990s saw introduction of the Western literature on critical studies of discourse. But only a small number of articles on ideology and translation have been motivated and published in major Chinese journals. Besides, focusing on the past rather than the present, those articles sometimes get bogged down in conceptual misinterpretations and are usually too descriptive and conceptual to be of real help.

This essay examines the ideological dimension of translation studies in present-day China, which can be viewed as an indicator of any discernible change in ideological fluctuations of translation. As far as I see, the ideological dimension to translation studies concerns two aspects: ideology in critical and theoretical translation studies.

\section{Ideological Reason for Scarcity of Critical Studies of Translations}

Traditional critical studies of translations in China have been confined to language-oriented error studies. Recently, the horizons have been broadened to include cultural and historical perspectives. Scholars have looked down upon these studies, viewing them as being inferior to their theoretical counterparts in academic or scholarly value. But of course, there are deeper social reasons for this general discrimination against critical studies of translations.

After 1979, reforms in Chinese universities tended to keep pace with those social ones and quantitative systems for faculty evaluation were established. According to these systems, academic essays are graded by the status of the publishers or sponsors of professional journals. Those published in the so-called central journals get the highest credit while those in the nation-state leveled journals, the provincial journals, and ordinary journals get lower and lower credits in sequence. To complicate matters still further, many local colleges of foreign languages subdivide the central journals on humanities, language and translation studies into authoritative, central and quasi-central journals. Also, the evaluating systems have set forth the number of academic essays that must be published in journals at certain levels if a faculty member wishes to obtain the position of lecturer, associate professor or full professor. Of course, universities are autonomous in making such decisions.

Under these circumstances central journals try to keep up academic influences either by soliciting established professors for essays or by giving the highest priority to theoretical essays. This orientation makes translation reviews or critical studies of translations unfavorable for both editors and would-be contributors because they are sometimes theories-proof, usually time-consuming and invariably get lower points for their authors. In addition, because of the critique-phobia in Chinese translation studies, some scholars believe that it is better to substitute translation activities criticism for translation criticism. But this suggestion aims to applaud successful translations of established translators or scholars and in its own way contributes to the prevailing view which has confined critical studies of translations to the linguistic field and takes language-oriented critiques of translations as low-leveled. It in turn discourages scholars from raising questions in linguistic, cultural, social and historical aspects against well sold translations or those produced by prestigious professional translators or university professors and elbows critical studies of translations into a far corner of the academic stage. Absence of translation criticism, 
especially from the perspective of language quality and cultural consciousness, deepens the gap between theories and practice in Chinese translation studies, the fact of which has provoked openly voiced doubts about the legitimacy of theoretical studies in China. Actually, much can be done in critical studies of translations as regards the ideological implications of a translator's discursive strategies and the selection, distribution and reception of a translation. More efforts from Chinese translation scholars in this respect are needed for the healthy development of translation studies as a discipline.

Critical studies of translators' discursive strategies may serve as a first step in this direction because "Language does not operate in isolation. Meanings always get made in contexts where social expectations and non-linguistic symbols play a role" (Lemke 1995: 8). It has been agreed (e.g. Larrain 1994; Lemke 1995) that the ideological implications of discourse are connected with power-related factors such as gender, ethnicity, educational background, and the status of a particular culture. A translator's discursive inclination speaks of his/her personal ideology as the stamp from his/her educational background, or from the social group or sub-culture to which s/he belongs. Besides, it may be molded by external pressure such as the dominant ideology of the receiving culture and the imposition by the initiator or the patron of the translating project.

Critical studies of the selection, distribution and reception of translated texts are also important. From 1950 to 1978, it was the political agenda of the government (i.e. proletarian dictatorship) that determined the judgments and evaluation of a literary work of either foreign or domestic origin, which followed that the selection of a text to be translated and a translator's textual strategy were politically overseen and controlled by power institutions - prestigious state-owned publishing houses and the China Foreign Languages Publishing and Distribution Administration as the official agency in charge. Since 1993, readership has become the decisive factor for the reception of a translation because of the legitimized market economy. As a result, the decisions of a translator or a translation scholar can be affected by personal estimation of the preference or the taste of the potential audience. At the same time, the ruling ideology shared by the social groups to which the receivers belong is carefully weighed in production and distribution of a translation.

Generally speaking, critical studies of translations carried out from the ideological perspective may be contextualized by the socio-historical or socio-cultural elements of the receiving culture and usually focus on the interactions between the dominant ideology of the indigenous culture and (1) linguistic strategies of certain translations or a single version and the personal stance of their or its translator(s), (2) the motivation(s) of selection of the text(s) to be translated, (3) the distribution and reception of certain translations or a single version.

And, much more attention should be paid to the position of a particular translation scholar concerning the prevailing ideology of the target culture which forms the ideological context for translation production. Regardless of the historical or here-and-now perspective taken by the scholar, his/her attitude to the ruling ideology of the receiving culture ranks as the most important element of critical studies. If a translation scholar identifies with the mainstream ideology, s/he will endorse the textual reflections of the mainstream ideology in the target text, and will agree with a translator on the adopted translational strategies that accord with the ideology in question. If a scholar remains critical, s/he will challenge the restrictions imposed on the production, distribution 
and reception of a translation by the prevailing ideology of the domestic culture and disapprove of a translator's obedience or subservience, but will support a translator's efforts in resisting the foregoing restrictions or rejecting to conform.

\section{Chinese Cultural Identity: Divided by Ideology}

The divisive issue of Chinese cultural identity appeared as early as the late Qing period $\left(1840^{1}-1912^{2}\right)$ and became an ideological hot potato in the May 4th Movement of 1919.

In the late Qing period, Chinese scholars and government officials formed two camps: the conservative that identified with traditional Chinese culture and the radical that were sympathetic to Western cultures. The conservative were true to the Confucian philosophy as the basis for social institutions and ethical rules, and they stuck to the old language system which were characterized by using traditional characters and the division between the written form and the oral form. ${ }^{3}$ The radical intellectuals believed that it was urgent for Chinese people to learn from the West in civil and military technology and other aspects of social life (e.g. new hair or dressing style, coeducational schools and colleges, etc.). For a country with a feudal history of more than 2000 years, the radical seed could not find favorable soil for itself to grow into a big tree before the imperial system broke up. Though the radical voice was unpleasant for the ruling royalty, it did bring some changes to the social life of Chinese people in the late Qing period.

Later in the May 4th Movement, the radical became the dominant side and the conservative turned marginal. There is a difference between the two periods though they both aim for a stronger country. Because of the capture of Beijing by the Allied Forces ${ }^{4}$ in 1900, the radical intellectuals of the late Qing period regarded the West as the adversary or enemy and they wished to avoid repeated failure in encounters with the Western invaders by learning from them. They had no intention to discard traditional Chinese culture in this learning process. On the contrary, the radical scholars of the May 4th Movement regarded the West as the model and insisted that Chinese people should discard traditional culture as well as the old language system. An innovation to the Chinese language was then achieved: new words were borrowed in the main from Japanese and English and new grammatical rules were borrowed from English. People used to employ a simple character to indicate the pronunciation of a complicated character in ancient China. In 1918, right on the eve of the language innovation, an alphabetical system was adopted for indication of a Chinese character's pronunciation and gave the language innovation an extra push.

The 1937-1945 Sino-Japanese War spared little room for scholars to care about cultural problems. When the People's Republic of China was founded in 1949 after years of civil war, the new government spared no efforts to accomplish centralization of state power. What had been pushed to the top of the priority list of the new government was thorough reform of the social institutions, government agencies, life styles, ideas and values, etc. At that time, the exemplary model officially acknowledged by the newly founded People's Republic of China was the ex-Soviet Union. Before the friendship between the two countries was in a mess in 1960, any attempt at Westernization in whatever form was unacceptable and politically condemned. In the meantime traditional Chinese culture was severely criticized as harmful and useless, belonging to nowhere 
except the trash can. For another 7 years after 1960, China had been toddling along that line, dreaded the "decadent" Western influences and distained the "rusty" traditional cultural heritage. Autonomy of culture remained a luxury for China from 1966 to 1976 when Chinese intellectuals of clear conscience found the nation's political agenda unreasonable but were made silent.

After the Reform and Opening Up in 1979, cultural concerns were highlighted together with political and economic reforms. Once again China felt the urgency in learning from the Western countries and realized the importance of opening up and rejoining the world in the establishment of new political and economic order. Though there were suggestions as to the preservation of the traditional cultural heritage, they did not occupy the central place of the cultural arena. The immediate concern of the majority of Chinese people has been the modernization of China at whatever costs, which has produced numerous changes in life styles, law practice, academic life, policies and regulations, ideas and value systems, etc. It brings about the elevated status of the English language in China. And the government's language policy provides institutional support for that elevation. Nowadays, a lecturer or an associate professor must pass an examination of English competence before she or he can apply for a position of an associate professor or a full professor if the person does not hold a Ph.D., which has been termed as the "institutional appendix" of China. Even if academic articles are published in Chinese journals, scholars must provide English translations for the titles and abstracts. And from 1985 to 2005, undergraduate students except English majors had to pass the CET-4, an exam that tests the students' proficiency in English held by the country, in order to get the Bachelor's Degree. The tie between the Bachelor's Degree and the CET-4 score was only dissolved lately.

Since 1979, the debate between the radical and the conservative has been a one-sided game, but the conservative as the weaker side never gives up. This is the reason why the split in ideology reappears at intervals of every several years. The most recent revival of this ideological division was in the second half of 2004. Some influential public figures ${ }^{5}$ have commented that cultural conservatism has been motivated by a series of events: the serial lectures on Confucianism at Longchang, the 2004 Cultural Forum for Celebrities held in Beijing, and the official sacrificial ceremony for the $2555^{\text {th }}$ birthday of Confucius.

Longchang, a place of Guiyang, the provincial capital of Guizhou Province, is known because of a Confucian philosopher of the Ming Dynasty by the name of Wang Yangming. From July $10^{\text {th }}$ to $17^{\text {th }}, 2004$, a retired teacher of Shenzhen Administration College had invited some prestigious culturally conservative scholars ${ }^{6}$ to Longchang to give a series of lectures under the heading of "Current Destiny of Confucianism."

From September $3^{\text {rd }}$ to $5^{\text {th }}$, Xu Jialu, Ji Xianlin, Chen-Ning Yang, Ren Jiyu, and Wang Meng initiated the 2004 Cultural Forum for Celebrities, which was sponsored by the China Culture Promotion Society and was attended by 72 celebrities. At this conference, "Jiashen ${ }^{7}$ Cultural Proposal" was signed and promulgated, which had incurred critiques soon after its publicity. Sharpe attacks on the proposal mainly concern three aspects: the impropriety for calling on the government to interfere with cultural problems, the inadvisability of cultural protectionism, and the exaggeration of the positive function of the indigenous cultural tradition ${ }^{8}$. But the most insightful critique comes from Zhu Xueqin (2004), who has rightfully remarked that the May 4th Movement 
is wrong to regard the traditional cultural heritage as burdensome luggage to be thrown away for a faster trip towards modernization, yet it is inadvisable to mistake institutional issues for cultural ones. In a word, the social problems of China won't be solved by a mere change in the mainstream cultural position or ideology.

On September $28^{\text {th }}$, in Qufu, Confucius' hometown, the sacrificial ceremony for the $2555^{\text {th }}$ birthday of Confucius was hosted by officials from the local municipal government. The mayor of Qufu read the eulogy to commemorate Confucius as the teacher and model for thousands of generations. This is the first time for the local government to dip a finger into a traditionally non-governmental activity. Negative remarks from the media had poured in right after the event.

Of course, the surge of cultural conservatism does not come into being out of thin air. In 2004, broadband users in China increased by 25.4 million, a $146 \%$ growth comparing with 2003 . This boom in internet usage has also been accompanied by a preference for websites of mainland China that employ simplified Chinese characters. According to the $15^{\text {th }}$ report $^{9}$ of China Internet Network Information Center released on January $1^{\text {st }}, 2005$, of all the information sought by the Chinese internet users, only $10.3 \%$ comes from English websites and 7.0\% from Chinese websites outside mainland China. This preference for Chinese websites helps the 94 million internet users in China to forge closer tie with their mother language, which affects the identification with the national cultural identity. Consequently, some people even went beyond the border for regaining cultural confidence and sank into the quicksands of cultural conservatism.

Though the controversies concerning the ideological division in terms of Chinese cultural identity were not remarkable enough to change the mainstream ideology of China, which proves to be more radical than conservative, it is too early to announce that the conservative side is the loser because pressure has been imposed on the State Administration of Radio, Film and Television of China (SARFT), who has promulgated a Code of Professional Ethics for Radio and TV Hosts and Announcers ${ }^{10}$ that requires the radio and television hosts and announcers to avoid imitating their Taiwan and Hong Kong peers on Taiwan and Hong Kong accents or dialects as well as sandwiching unnecessary English words between Chinese ones. Since 1993, official agencies of the Chinese government have favored the non-interference policy on cultural issues. In this respect, the Code endorsed by the SARFT might be regarded as a minor progress achieved by the conservative. But as far as I have noticed, the announcers and hosts of provincial or local radio or television Channels have not changed their speaking style as required. It is hard to tell whether the Code will be able to make changes as the conservative wish.

\section{Ideological Examination of Two Major Theoretical Orientations}

From 2000 onwards, translation studies in China have been successful in attracting scholars' attention both as a blooming discipline and a fruitful territory. The number of faculty members of colleges of foreign languages engaged in translation studies, which was once regarded as a marginal or subordinate research orientation for linguistics, foreign literature or comparative literature, keeps on increasing. At the main time, newly published Chinese literature on translation has exhibited two major theoretical orientations in spite of the variety of research interests, which are manifested in 
several representative essays appeared in the Chinese Translators Journal (one of the so-called central journals) sponsored by the Translators' Association of China. The split in the cultural position of Chinese society is responsible for the conflicting ideologies embedded in the theories and the ideologies reflect no other than the contradictions between the self and the other or more exactly, the local and the global.

One theoretical orientation advocates adding Chinese characteristics into translation studies in order to gain one's own voice as a Chinese scholar instead of echoing what has been said in Western academic literature, which may be termed as the conservative position characterized by two essays by Zhang (2002) and H. Sun and Zhang (2002).

As the newly appointed director of the Committee of Translation Studies and Teaching, a sub-agency of the Translators Association of China, Zhang's viewpoints are representative and demand close examination if we need to understand the present situation of Chinese translation studies though the views have not been organized as a regular academic essay. According to Zhang (2002: 58-59), the establishment of a theoretically modern framework of Chinese translation studies is the top priority for Chinese scholars, the most important of which is a re-interpretation of the classical Chinese literature on translation that is internationally significant for theoretical studies. What this proposal tries to do is to rewrite the self with capital letters, which turns the specificity of domestic situation into a good excuse to reject the Western literature on translation. He insists that scholars must try to distill the cultural insights of the canonical documents from this attempt of re-interpretation in order to cultivate a translation theory of modern Chinese characteristics. Also, it is crucial to carry out case or data studies as regards the Chinese history of translation. Seemingly legitimate, Zhang has attempted to imply that local knowledge and cultural heritage is the panacea for the global pain suffered by Chinese scholars. On the pretext of differences between languages, cultures and educational systems, some Chinese scholars are sympathetic with this exclusive attitude towards the Western literature on translation.

It must also be noted that $\mathrm{H}$. Sun and Zhang (2002) coauthored an academic essay about a similar topic in the next issue of the journal. They have argued that Chinese scholars have been forced into silence on the international academic arena because they have no access to discursive rights. This argument is an ill-grounded one that puts the cart before the horse. For one thing, it is the domestic climate rather than the international one that needs fresh air as far as freedom of academic research is concerned. Though freedom of academic research has been endorsed by the Chinese government since 1979, the editors of academic journals and professors at universities have not fully understood the spirit of this hard earned freedom. There have been many complaints ${ }^{11}$ about the major academic journals' becoming garden parties for some influential professors, their friends and former students. Before they have their voice heard by international colleagues, Chinese scholars still have a long way to go in order to talk freely and critically at home. For the other thing, dialogues not only require common topics but also common language and terminology. If you speak English, French or Spain while I only speak Chinese, how can we understand each other and enter into a conversation without an interpreter? Rights are not always granted but can always be won. In order to understand and be understood, we must all learn to speak languages other than our own and explore the secrets of translation. 
A point echoed by some scholars is that "consensus" (Sun and Zhang 2002: 5) should be reached as to how to carry out translation studies in China. This proposal is impractical if the "consensus" refers to the so-called new framework of translation studies distinctive with Chinese characteristics whose central idea is the recognition of a homogenous theoretical basis - the domestic literature on translation of historical significance. This narrowing down of research horizon is against the prevailing tendency of diversity and open-mindedness of our age. No consensus should be imposed on translation studies unless scholars make the choice out of free will because a well-meaning proposal of consensus may turn out to be the collaborator of uncontrolled power in suppression of different viewpoints. China had suffered the consequences during the Cultural Revolution, which had turned out to be the burning inner infection that took a long time to be treated. No way for Chinese scholars to forget the lesson so soon and wish for artificial consensus.

In a word, isolation or restriction has never been proved as a good policy either for translation as a fledgling discipline or for Chinese culture as a culture in transformation. It must be noted that misconceptions about local and global situations resulted from cultural isolation or misplaced narcissism can be misleading for the reconstruction of the national cultural identity and must be guarded in both translation studies and cultural policies.

The other theoretical orientation sympathizes with the foreignizing approaches to translation and holds that these approaches contribute to improvements in modern Chinese language and indigenous culture. Marked by two articles by Z. Sun (2002) and Wu (2003), it may be termed as the radical perspective. Since 1979, the Chinese government has loosened control on cultural matters and has adopted a cultural policy of non-interference after the legitimization of the system of market economy in 1993. If government officials were invited to give comments on cultural issues, they would definitely say that the traditional cultural heritage and Western influences were both needed for the healthy development for Chinese culture. Against this background, despite the fact that Z. Sun and Wu are from a military academy, the PLA Institute of Foreign Languages, their cultural positions stay much more closer to the pro-Western version of the prevailing grassroots cultural ideology.

What must be pointed out is that Chinese scholars engaged in debates over the domesticating and foreignizing approaches to translation ${ }^{12}$ have de-contextualized the original context. As a translational strategy, foreignization means resistance to Anglo-American cultural hegemony for Venuti, who has aimed at translations from minor languages into English as the dominant language. Venuti's targets are the cultural narcissism of Anglo-American countries and the asymmetrical power relationship between the first world and the third world. Yet according to Z. Sun (2002), the reason for him to advocate the foreignizing method and to predict that it will bring about a prevailing tendency of foreignization in literary translation production in China in the $21^{\text {st }}$ century is the method's two major strengths: its remarkable role in the development and maturity of the Chinese language, which has been described by him as being "short of words and monotonous in sentence structure" (ibid.: 41); its ability in infusing new blood into Chinese culture. This reasoning echoes the radical side of the afore-mentioned split in cultural position yet is unreasonable and problematic in more than one way. Firstly, questions must be answered before 
such a prediction is made: What does "a prevailing tendency in the production of translations in the $21^{\text {st }}$ century" mean? Does that imply an overwhelming majority? How to calculate the frequency of the domesticating and foreignizing approaches being employed? Secondly, the underestimation of the quality of the Chinese language betrays exactly the scholar's inner crisis in recognition of his personal cultural identity. The author may deny this. But if a person identifies with his/her culture s/he will not speak harshly and disdainfully against his/her mother tongue because "What gives people a sense of identity is a shared culture mainly manifested in a shared language" (Larrain 1994: 27).

The crisis in identification with indigenous culture in disguise of underestimation of the language of that culture has been time and again treated as a matter of cultural mentality. In support of Sun's idea, Wu (2003: 15) makes a proposition of cultural confidence as manifested in a poetic quotation from an ancient poet of the Tang Dynasty: "Luohua tajin you hechu, xiaoru huji jiusi zhong (literally: Where did they go after every petal of the fallen flowers had been trodden upon? They laughingly entered the bars where $\mathrm{Hu}$ girls served as waitresses)". It is inadvisable for the author to quote this line as the example for cultural confidence and courage in embracing foreign culture because the line has particular implications ${ }^{13}$ for someone who is familiar with Chinese history. In the two consecutive dynasties of Han and Tang, $\mathrm{Hu}$ referred to the nationalities that had lived beyond the northern border of China. Some of them were businessmen who came to China from former enemy countries that had been defeated or dissolved. Later, they turned out to be immigrants of ancient China and took up the jewel or wine trade for life. At that time, a large number of young girls of $\mathrm{Hu}$ were hired as singers, dancers or waitresses by the bars selling expensive wines imported from foreign countries beyond the northern border of China. And these girls were the flirting objects of wealthy customers of Han, the major ethnic group of China, and might be chosen as sexual partners by traveling businessmen and local officials, who were far away from their hometowns and families. The poetic line not only depicts the historical fact ${ }^{14}$ but also betrays a sense of ethnic superiority and disrespect for women. ${ }^{15}$ The quotation actually provides in a sense the evidence of ethnocentrism which is far from what the scholar intends to express. This deviation from the original intention speaks of estrangement to one's own culture and language which must be guarded against in Chinese translation studies.

Further, it is unconvincing to conclude that open-mindedness and cultural confidence imply embracing all the differences indiscriminately. It is too ideal to be practical in respect of rational judgments and critical analyses.

\section{Conclusion}

Examination of and reflections on the ideological dimension of translation and translation studies in contemporary China may be thought-provoking for translation scholars because of their influences on the reconstruction of Chinese people's cultural identity in a global age. The link between ideology and translation studies does not concern a matter of being or not-being, and the "purity" of studies in the humanities is no more than a utopian illusion. In this sense, Chinese scholars need to maintain critical detachment in order to gain a panorama of the cultural situation and to fight against unfair power distribution or manipulation in the academic field and social life. 
The most urgent problem is the domestic climate for the social, cultural, political, and institutional sub-systems of Chinese society. It is inadvisable to take the traditional cultural heritage or Western influences as the excuse or panacea for current problems in China. Local knowledge can be trivialized if cut off from the global setting, and the global setting becomes meaningless if local knowledge is ignored. Therefore, Chinese translation studies must draw on Western literature while carry out historical studies of domestic cases. And, it is impractical to wish that all translation scholars in China to go into one direction. As a discipline under construction, translation shall not refuse branches if it wants to become a broad river. When the water covers a wider area and the river comes into being, there will be no need to worry about where it should or will go. In a word, ideological studies of translations, translation activities or theories await sharp eyes and sober brains. And the more, the better.

\section{NOTES}

1. That year saw the outbreak of the Opium War.

2. The year in which the Xinhai Revolution had overthrown the Qing government.

3. The written form and the oral form were different in words and syntax.

4. The Eight-Power (i.e. Britain, the United States, France, Germany, Japan, Russia, Austria and Italy) Allied Forces.

5. e.g. Xue Yong and Zhu Xueqin

6. e.g. Sheng Hong, Kang Xiaoguang, etc.

7. It refers to the year of 2004. It is the way of numbering the years according to the Heavenly Stems and Earthly Branches in the lunar calendar of China.

8. For reference, a reader can read "On 'Jiashen Cultural Proposal"' by Yuan Weishi, which was published in Southern City, a newspaper, Page A03-04, on September 21 2004.

9. The report can be downloaded at http://www.cnnic.net.cn/html/Dir/2005/01/18/2744.htm.

10. The code can be found at http://www.sarft.gov.cn/manage/publishfile/35/2340.html.

11. A large number of Chinese essays on that topic can be found by using Google or Baidu's search box.

12. The September issue of the Chinese Translators Journal in 2002 alone published 5 articles on foreignizing and domesticating approaches to translation with conflicting positions.

13. For more references, please find Zhang Qinghong's "Hu Girls and Bars in the Tang Dynasty" at http://www.wenyi.com/yinshi/wine/read.asp?id=1606\&indexword and Wang Qing's "Tales about Foxes in Ancient China: Portraying Hu People out of Cultural Prejudice" at http://www.confucius2000.com/poetry/zgzqhggswhpjxdhrxx.htm.

14. i.e. where the aristocratic dandies of Chang'an, the Capital of the Tang Dynasty, went for fun.

15. The laughing attitude towards women described in the poetic line was considered as frivolous for men of the Han nationality in ancient China. 


\section{REFERENCES}

HATIM, B. and I. MASON (1999): The Translator as Communicator, London and New York, Routledge.

LARRAIN, J. (1994): Ideology and Cultural Identity: Modernity and the Third World Presence, Cambridge, Polity

Press.

LefeVere, A. (1992): Translation, Rewriting and the Manipulation of Literary Fame, London and New York, Routledge.

Sun, H. and B. ZHANG (2002): "Universality vs Difference - On the Development of Contemporary Translation Studies in China", Chinese Translators Journal 2, pp. 4-7.

Sun, Z. (2002): "China's Literary Translation: from Domestication to Foreignization”, Chinese Translators Journal 1, pp. 40-44.

Venuti, L. (1995): The Translator's Invisibility: A History of Translation, London and New York, Routledge.

Wu, N. (2003): "Translation: Towards the Fusion and Accretion of Different Cultures - On Retaining Source Text Diversities in Translation”, Chinese Translators Journal 3, pp. 13-17.

ZhANG, B. (2002): "Studies of Translation Theories in a Context of Globalization", Chinese Translators Journal 1, pp. 58-59.

ZHU, X. (2004): "Resurrection of Conservatism in Cultural Position", <http://www.nanfangdaily.com.cn/southnews/zt/2004zmnztk/2004zggc/200412300115.asp>. 